DOI: $10.15503 /$ jecs20162.307.315

\title{
TRANSLATING ANNA KARENINA - TO THE QUESTION ABOUT THE PRAGMATICS OF TRANSLATION
}

\author{
EKATERINA GURINA
}

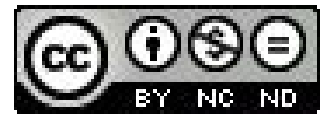

\author{
St.Tikhon Orthodox University, Faculty of Philology, \\ 23-5A Novokuznetskaya St., Moscow, 115184, Russia \\ E-mail address: bestengteacher@yandex.ru
}

\begin{abstract}
The article deals with the stylistic peculiarities of the translations made by $\mathrm{R}$. Pevear and L. Volokhonsky, L. and A. Maud, J. Carmichael of the novel Anna Karenina by L. Tolstoy on the basis of pragmastylistics and comparative analysis. It tries to analyze the text of the novel using the lingo-stylistic characteristics in accordance with the national bias in the way of thinking and individual creative preferences of every translator taking an attempt to introduce a foreign picture of the world to his countrymen. It underlines the impact of Tolstoy's complicated attitude towards the customs and traditions of the Russian Orthodox church and the specific relationship of the author of the novel with God and its manifestation in the description of the heroes' characters. In stresses how vital it may turn out to preserve the author's ideostyle - lexis and syntax (the word order, the choice of them and the length of the sentences) for the successful interpretation of the writer's views and stance by the reader.

Key words: idiodialect, idiostyle, pragmatics, pragmalinguistics, pragmastylistics, translation, semiotics, stylistics, style.
\end{abstract}

The issue of translation has been of great interest for many well-known linguists, philologists, literary critics and writers in Russia and abroad, for example, V. Nabokov, I. Brodsky, K. Chukovsky, S. Marshak, A. Fedorov, A. Schweitzer, V. Komissarov, L. Barkhudarov, the German philosopher and theologian F. Schleiermacher, our contemporaries S. Tyulenev, G. R. Gasparyan, S. G. Ter-Minasova, L. Venuti, Hochel, Hatim,

As it is known, every translation can be considered from the point of view of its adequacy and equivalence on the lexical and grammatical level, as well as artistic one. The interest of readers to classic works is unabated. The proper delivery of ideas and thoughts of the author by means of another language is becoming particularly relevant. Translation may be a domesticating or foregnizing process. According to Venuti (1995) domesticating translation is "a replacement of the linguistic and cultural difference of the foreign text with a text that is intelligible to the target-language reader. Foreignizing transla- 
tion is defined as a translation that indicates the linguistic and cultural differences of the text by disrupting the cultural codes that prevail in the target language. Other scholars, like Tymoczko (1999), criticise this dichotomy by pointing out that a translation may be radically oriented to the source text in some respects, but depart radically from the source text in other respects, thus denying the existence of the single polarity that describes the orientation of a translation...Modern English language readers are more familiar with Russian language, literature and culture as well as with Tolstoy's works than the 19th century readers were....adequate representation of a text in a different language becomes more challenging" (Birdwood-Hedger, 2006, p.3).

How much can translations differ from the original? What can a translator of a literary work afford? V. Komissarov, giving a definition of translation, provides "adaptive transcoding" as "a type of linguistic mediation, in which not only transcoding (transfer) of information from one language to another (which occurs in case of any translation) takes place, but also its transformation (adaptation) in order to state it in another form, shaped by the organization of this information in the original, and the special challenge of crosslanguage communication." (Tolstoy, 2010, p.48). These tasks can be different: 1. The adaptive translation for studying the original language. There is an adapted translation of Anna Karenina: Anna Karenina (abridged). - In: The works. One volume edition. New York. Black, 1928.

2. The creation of options, from which the whole pieces are excluded:

2.1. For censorship reasons: the puritanical "I beremenna", used in one of the early translations of the novel - the Anna's answer to Vronsky, invoked Nabokov's indignation. In his the opinion the "selfish translator furnishes the boudoir of Scheherazade to his taste" (Nabokov kak perevodchik).

2.2. Because of the desire to make life easier for the reader, to make the translation of the novel "reader friendly" by excluding complex philosophical thoughts, unnecessary scenes from the point of view of the translator. For example, the Russian translator of the novel "War and peace" has left only the scenes, describing the life of the aristocracy, taking into consideration the tastes of the public[8]. This technique is rather popular today. Recently a publication has been released that is based on the draft (which maybe fake) of the book that has no episodes of the war at all. [1]

Reduction in translation may happen due to the lack of competence of the translator. K. Garnett -one of the first and the most popular translators of Russian classics, omitted lots of the text, because she couldn't understand it, but Nabokov treated them more leniently than intentional distortion.

The desire to make life easier for the reader may, of course, contribute to the commercial success of the publication, but does reader benefit from it, does it help to understand the culture of other peoples or centuries? Comparing the difference between C R. Edmonds' and Garnett's translations, L. Schillinger gives an example from personal experience of how cultural details help intercultural communication of different nations and epochs: "A few years ago I read the translation by Rosemary Edmonds, who left the 
French dialogue in the first scene of the novel at Anna Pavlovna Scherer's . And that's when I first realized that I'm reading a book not just about rich people, but about Russian aristocrats. This alone has painted the whole novel anew, and made it more intimate, helped to move my 70-ies of the 20th century to the beginning of the 19th in Russia" (As the novel "War and peace" becomes the novel "War and Peace"). On the other hand, J. Carmichael insists that the use of patronymics in the English translation of Anna Karenina should be completely unnecessary. He believes that undoubtedly the advantage of his translation should be the usage of the language that is more akin to modern speech [1]. Nabokov wrote about this kind of translators: "Instead of joyful rest in the arms of a great writer, he worked tirelessly for little reader..."[8]. But it's worth mentioning that this type of translator actually robs the reader of the opportunity to enjoy the national colors, to understand the mentality of the people.

When even small details are so valuable, how flawed is the text of translation after serious reductions. Fortunately, the novel Anna Karenina was not subjected to serious deliberate distortions, but here is an example of how a small omission affects the reader's perception of the characters. L. Tolstoy writes about Steve Oblonsky: “Степан Аркадьевич был человек правдивый в отношении к себе самому. Он не мог обманывать себя и уверять себя, что он раскаивается в своем поступке. Он не мог раскаиваться теперь в том, в чем он раскаивался когда-то лет шесть тому назад, когда он сделал первую неверность жене. Он не мог раскаиваться в том, что он, тридцатичетырехлетний, красивый, влюбчивый человек, не был влюблен в жену, мать пяти живых и двух умерших детей, бывшую только годом моложе его." (Volkov, 2013, p. 9). J. Carmichae translates: “Oblonsky was honest with himself. He could not deceive himself by telling himself that he repented of his conduct. He couldn't feel repentant that he, a handsome, amorous man of thirty-four, was not in love with his wife, the mother of five living and two dead children, who was only a year younger than he." (Tolstoy, 1960, p. 3). Tolstoy's sentence, where he points out that Steve still had remorse in the beginning (although it was quite a long time ago - six years), is translated by none of the chosen translators. Such unanimity is rather interesting. What is it caused by? It is not translated by R. Pevear and L. Volokhonsky, who claim to have produced a translation that is the most close to the original. One can't find it in the translation by E. and L. Maude, who were acquainted with L. Tolstoy. They used to live in Russia and could understand the importance of this sentence for the perception of Steve's inner world, his struggle with himself, the contradictions of his nature, reflecting Tolstoy's own life experience. On the one hand, he had imbibed the tenets of Christian morality since his childhood, and on the other hand, the typical upper class idea that adultery was nothing special.

Of course when a wife leaves her husband for her lover - it's a scandal, she's a harlot and ought to be deprived of the right to see her son in order to protect him from her evil influence. But Steve's love affair with his children's 
governess is quite natural. It is impossible for a man to love his wife after so many years of marriage. It could be possible to ignore the sentence about Steve unless it contained some important information characterizing Oblonsky. Tolstoy explains that Oblonsky had once possessed a certain amount of decency, though he had always been a passionate and frivolous person. Six years before that accident, he had felt sorry and ashamed for his behavior when recollecting his wife and thinking about God (as he had been raised in the Orthodox tradition). But his spirit and the habit to refuse nothing suppressed the moral principles. He'd found an excuse for himself - the wife was only a year younger than him, had born a whole bunch of children and should have understood herself that he couldn't love her. After that cheating and adultery become quite natural and easy for him. That is exactly what Tolstoy used to think in his youth, but contradicted to L. Tolstoy's point of view at the period of time, when he was writing Anna Karenina.

The French and Russian authors often if not always write about adultery. But if we compare the books by Zola and Tolstoy one can't neglect the fact that the difference between them lies in the attitude of the authors towards it. Zola describes the ways of manifestation of passion among people in love and Tolstoy does a research of the moral aspect of passion, its disastrous consequences for one's soul, what way the sin conquers and destroys it and, finally, one's life and body. L. Tolstoy shares the Christian tradition not to criticize people, not to oppose the evil with force but to feel painfully sorry for them. The Orthodox tradition pays lots of attention to repent and confession, that's why L. Tolstoy can't help mentioning that trait of character when speaking about Steve.

All this is obvious, for those who read the Russian text, but it remains unknown to the English readers. In English translations the word "repent" is used only with negation. L. and E. Maude: "He was incapable of selfdeception and could not persuade himself that he repented of his conduct. ", „couldn't feel repentant" (Tolstoy, 2010, p.4), R. Pevear and L. Volokhonsky: "He could not deceive himself into believing that he repented of his behavior. He could not now be repented that he, a thirty-four-year-old, handsome, amorous man, did not feel amorous with his wife, the mother of five living and two dead children, who was only a year younger than he." (Tolstoy, 2004 , p. 3). And L. N. Tolstoy wrote that he had „repented”. K. Garnett's translation was one of the first (1901) and it is considered a classical one, but it doesn't contain this sentence too: „Stepan Arkadyevitch was a truthful man in his relations with himself. He was incapable of deceiving himself and persuading the fact that he, a handsome, susceptible man of thirty-four, was not in himself that he repented of his conduct. He could not at this date repent of love with his wife, the mother of five living and two dead children, and only a year younger than himself." (Tolstoy, Anna Karenina, http:/ / literatureproject.com/anna-karenina/anna_2.htm).

In the first English translation, made by N. X. Doul and published in NewYork in 1899, that part was omitted too: "Stepan Arkadyevitch was a sincere 
man as far as he himself was concerned. He could not deceive himself and persuade himself that he repented of his behavior. He could not, as well, feel sorry that he, a handsome, susceptible man of four and thirty, was not now in love with his wife, the mother of his five living and buried two children, though she was only a year his junior." (Tolstoy, Anna Karenina. Translated from the Russian by Nathan Haskell Dole).

There is one more inaccuracy in the translation, so that the image of Oblonsky varied greatly from the original. The translation of the word "козырь" аs a "trump” (R. and L. Piver Volokhonsky) in the sentence: "Well, Dolinka," he said to the eldest daughter, is your trump what's he doing?" (Толстой, Анна Каренина [Anna Karenina], p. 37) is absolutely impossible. „Козырь” in the "Explanatory dictionary of the living great Russian language" has a value of -a man that is brisk, agile, brave, good, grip. Translators L. and E .Maudy and J. Carmichael

translate it as a "prodigal” - a person who leaves home and wastes money and time on a life of pleasure, but who is later sorry about this and returns home (Tolstoy, 2010, p.1203): 1. "and what's your prodigal up to?" (Tolstoy, 1960, p.144) 2." and what is your prodigal about?" (Tolstoy, 2010, p.167). This word doesn't coincide with the Russian meaning completely, it doesn't mean a "trump card", but corresponds to the context of the novel and the meaning that Tolstoy implied, because it is about Dolly's husband - Stiva Oblonsky, a flighty but contrite man, seeking to make amends to his wife. Pevear and Volokhonsky use the word "trump", a card belonging to the suit that has been chosen for a particular game to have a higher value than the other three suits (Tolstoy, 1960, p. 1644). They do not see that in the Russian text it differs greatly from the traditional meaning: „what's your trump up to?” (Tolstoy, 2004, p.121). This way they change the original idea of the author. Stepan Arkadyevich turns out to be a perfect spouse. But this is absolutely wrong. Steve is a source of endless problems and anxiety for Dolly .

It's impossible to translate a literary text properly without taking into account pragmatics (in particular, pragmalinguistics). "Pragmatics is a branch of semiotics that studies the relationship of someone using a symbolic system and the symbolic system" (As the novel "War and peace" becomes the novel "War and Peace"). What is extremely important is that it deals with the attitude of the translator towards the "source text" (Birdwood-Hedger, 2006, p.3). When it comes to artworks, the translation is carried out with certain limitations because not everything is amenable to literal translation.

"One of the key issues in the recent translation theories has been on whether the translator should remain invisible" - writes Birdwood-Hedger (2006, p. 3). But how much invisible should he be? It goes without saying that something has to be omitted or changed in every translation, but every translator should keep in mind that whether one likes it or not one is also a bearer of a certain idiostyle. I. Broadsky "scolded" C. Garnett for the distortion of the particular style of writers (Garmer, Constance. Wikipedia) He once said, "The reason English-speaking readers can barely tell the difference between 
Tolstoy and Dostoevsky is that they aren't reading the prose of either one. They're reading Constance Garnett." (Remnick, 2005)

Tyulenev writes that the translation can be considered as a text, "the improvement of which is the ultimate goal of translation studies", but you can approach it from pragmastylistic point of view, when the "pragmatics accesses the translation it is not for the sake of the translation, but in order to understand the original better by matching it with the original" (Толстой, Анна Каренина [Anna Karenina]). According to V. Volkov, idiostyle is an individual, specific verbal expression of "I" (one's ego) (Volkov, 2013, p. 21). He introduces the concept of "Philology of personality" (Volkov, 2013, p. 21). In those cases when the interpreter is a significant figure in literature (A. Pushkin. M. Lermontov), his or her translations often differ greatly from the original and start living their own independent life, because the "personality" of the translator has its own value. But it isn't so when we speak about the translators of "Anna Karenina" into English. Among those who translated the novel, were linguists, professional translators, but not world famous ones. K. Garnett is the only exception. She stands apart among them - a play was devoted to her life story.

Undoubtedly, the "theory of personality" of thetranslator affects thetranslation.L. Volokhonsky-animmigrantof theSovietperiod and a philologist-could notfail to seeall theflaws of thetranslation by K. Garnettand tried tocorrect them. But the translation prepared by her and her husband, aroused criticism not only among Americans, but Russians too. Trying to convey the peculiar Tolstoy's "style", they use calques and transliteration too overzealously and this way shifting Tolstoy's original logical stress: "Having finished the newspaper, a second cup of coffee, and a kalatch with butter, he got up, brushed the crumbs from his waistcoat and, expanding his broad chest, smiled joyfully, not because there was anything especially pleasant in his heart - the smile was evoked by good digestion" (Tolstoy, 2004, p. 8).

For a modern Russian-speaking reader the meaning of the word "калач" is not clear. We have to look it up in the dictionary in order to understand how it looks like. But we do not do that, we do not need it, because it does not interfere with the reading of the novel. This detail does not affect the relations of the characters, the events, our understanding of the characters. It doesn't matter for us, whether Stiva Oblonsky eats a roll with butter or a loaf of bread every morning. It is the feelings and thoughts of the hero that are important both for the author and for the reader. Ultimately, we are reading a novel of a great writer and philosopher, but not a cookbook. This sentence characterizes Stepan Arkadyevich vividly. We don't pay attention to the roll, but to the fact that he eats it with butter, which means that he is enjoying his prosperous life.

However: «КАЛА'Ч (или колач), калача, муж. 1. Белый хлеб, выпеченный в форме замка с дужкой. 2. Белый пшеничный хлеб вообще, в противоположность ржаному, черному (обл.). Нужда научит калачи есть....» [kalatch; small (padlock-shaped) white loaf 2 sources, pocket 
- shaped bun. KALACH (or Colac), Kalacha, m1. White bread baked in the shape of a lock with shackle. 2. White wheat bread opposed to rye, black (regional)] (Ushakov dictionary).

As we can see, the difference between" калач" and the usual white bread lies in its shape. Of course, for L. Tolstoy the form of the bread is not fundamental. Finally, Ushakov dictionary indicates that the word is a synonym of the regular white bread. Was there any need of transliteration in the translation? Perhaps it would have been easier to use a common English word „bun -a small round flat bread roll" (Oxford Advanced Learners Dictionary, p. 198) or the word "roll" which is" a small loaf of bread for one person" (Oxford Advanced Learners Dictionary, p.1318), and not to give a footnote: "A very fine white yeast bread shaped like a purse with a handle" (Tolstoy, 2004, p. 820). Moreover, it is not entirely accurate because a roll may have the form of a ring: «Кала́ (вар. Колач, от общеславянского kolač < kolo - ,круг') - у восточных и южных славян круглый белый хлеб, обычно в виде кольца или с небольшим отверстием; у западных славян так назывался любой обрядовый хлеб, в т. ч. свадебный каравай.» [„Kalach (var. Colac, from common Slavic kolač < kolo - ,circle') - Eastern and southern Slavs round white bread, usually in the form of a ring or with a small hole; for the Western Slavs it was the name of any ritual bread, including a wedding loaf."] (Ushakov Dictionary).

So did the other translators: „Having finished the paper, his second cup of coffee and a buttered roll, he got up, he got flicked some crumbs off his waistcoat, and, expanding his broad chest, smiled joyfully, not because there was anything specially pleasant in his mind -no, the smile was but the result of a healthy digestion." (Tolstoy, 2010, p.10).

Excessive transliteration transforms the novel into a textbook on geography. The word "калач” is not a stumbling block for a Russian-speaking reader. The English speaking readers are distracted by reading the footnotes, thereby paying less attention to the main thought of the author about the idleness and uselessness of the pastime, which is characteristic for Steve Oblonsky and many representatives of the nobility of that time. Much more important is a humorous characteristic that he had a smile on his face, caused by "good digestion" -" healthy digestion" (Tolstoy, 2010, p. 10), "good digestion" (Tolstoy, 2010, p. 8).

The fact is that an English reader will not even pay attention to it, absorbed in the study of the footnotes. This example can serve to illustrate Tyulenev's thought that pragmastylistic approach helps understand the original.

An example of a much more appropriate and even necessary transliteration is the word "zertsalo". Showing Prince Oblonsky's office to the reader, L. Tolstoy uses the word "зерцало". To find a replacement for this word in English is quite difficult, one has to describe the thing instead of using a lexical equivalent, since this is typically Russian and is absent in other countries. L. and E. Maude offer a "Mirror of Justice”, J. Carmichael - "the emblem of justice”. R. Peaver and L. Volokhonsky use transliteration "zertsalo" with 
a detailed footnote explanation :"A three-faced glass pyramid bearing an eagle and certain edicts of the emperor Peter the Great (1682-1725) which stood on the desk in every government office." (Tolstoy, 2004, p.820). This word requires explanation not only for foreigners, but for Russian readers as well these days. Its meaning it is obsolete and vague in modern Russia. 1.ЗЕРЦАЛО is a mirror (in church); allegorical. This man is the mirror of truth". 2." A triangular that stood with an eagle and three decrees of Peter I, on the Desk of every government office. 3. the old armor. Yandex.Dictionaries dictionary Dahl. - 1863-1866 (Slovari.yandex.ru).

It is mentioned by L. Tolstoy as an integral element of a government office and highlights the huge gap between what a clerk should do according to the covenants of Peter the Great, and what he really is busy with - tedious chicanery. It is no surprise that he does not miss any opportunity to waste his time being idle: “«Еще не было двух часов, когда большие стеклянные двери залы присутствия вдруг отворились и кто-то вошел. Все члены из-под портрета и из-за зерцала, обрадовавшись развлечению, оглянулись на дверь; но сторож, стоявший у двери, тотчас же изгнал вошедшего и затворил за ним стеклянную дверь.» (Толстой, Анна Каренина [Anna Karenina], p. 22).

L. and E. Maude's translation gives the reader a full idea of what was on the desks of officials, but does not explain in detail why. Translation "Mirror of justice" is a partial calques, which does not clarify much for the reader, but it's confusing because one immediately imagines a mirror, which is not quite right . J. Carmichael uses the best possible option - "the emblem of justice". He describes the object and explains its meaning, thus drawing the reader's attention to the word "justice" which is exactly what Tolstoy would like him to do, because the issue of justice, of the possibility to find it on earth was very vital at that time. At that time government offices were not the places where one could find justice easily. The poor were seeking for it. Some of the inteligentsiya were trying to fetch it for them, but L. Tolstoy doubted that and shared the views of the peasants and the Bible that only God could be the righteous judge. He proclaims in the epigraph of the book.

\section{CONCLUSION}

Undoubtedly L. Tolstoy possesses his own idiostyle, which J. Carmichael described as the lack of style in comparison with Proust or Henry James. Tolstoy does not seek external embellishment, and clearly tries to present the facts and the images of life as if through a camera lens (Tolstoy, 1960 p. 979-981). But every translator has his own idiostyle, which is formed as a result of an attempt to copy the author's style, but it bears the imprint of the translator's personal preferences. If J. Carmichael's aim is to create a readable translation, he chooses the appropriate lexical and grammatical forms: discards patronymic, selects simple but clear words, because the peculiar feature of L. Tol- 
stoy's style is simplicity.

The Maudes spent many years in Russia and were L. Tolstoy' good friends. It goes without saying that their style of translation, which turns out to be very accurate, was affected by that.

As far as L. Volokhonsky is concerned she is an adventurous person having emigrated from the Soviet Union in the 70-ies. The courage she possessed having introduced a new translation of Russian classics one can compare to her escape from the USSR. But not everyone welcomes extreme (both in life and in art).The philological identity of an interpreter should not hide from the reader the philological identity of great writers.

The short analysis of these three translations can easily show that 1.each translator has his or her own ideas, preferences, peculiarities and, thus, idiostyle; 2.each translator gives a special emphasis to different aspects of the "source text" (Birdwood-Hedger, 2006 p. 3); 3. each translator produces a book of his or her own; 4 . each nation reads a translated book of their own; 5 . it forms their own image of the author ; 5. their idea of the author differs from the idea of the book and its author that the nation the author belongs to has.

\section{REFERENCES}

[1] As the novel "War and peace" becomes the novel "War and Peace" - about the new translation of Tolstoy's prose". Retrieved August 1, 2016 from: http://www.svoboda.org/content/transcript/422754.html

[2] Birdwood-Hedger, M. (2006). Tension between Domestication and Foreignization In English-language Translations Of Anna Karenina. Edinburgh: University of Edinburgh.

[3] Garnett, Constance. Wikipedia. Retrieved from: https://ru.wikipedia.org/wiki/ Гарнетт,Constans

[4] Komissarov, V.N. (1990). Teorija perevoda (lingvisticheskie aspekty) [Theory of Translation (Linguistic Aspects)]. Ucheb.dlja in-tov i fak. inostr. jaz. - M.: Vyssh. shk.

[5] Nabokov kak perevodchik [Nabokov as Translator]. Retrieved August 1, 2016 from: knowledge. allbest.ruИностранные языки и языкознание..._0.html

[6] Oxford Advanced Learners Dictionary (2015). Oxford: Oxford University Press.

[7] Remnick, D. (2005). The Translation Wars. The New Yorker, 7.10.2005.

[8] Tolstoy L. (2004). Anna Karenina. Translated by Pevear, R., \& Volokhonsky, L. London: Penguin Classics.

[9] Tolstoy L. (2010). Anna Karenina. Translated by Maude, L., \& A. London: Collector's Library.

[10] Tolstoy, L. Anna Karenina. Retrieved August 1, 2016 from: http://literatureproject.com/ anna-karenina/anna_2.htm

[11] Tolstoy, L. (1960). Anna Karenina. Translated by Carmichael, J. New York: Bantham books.

[12] Tolstoy, L. N. Anna Karenina. Translated from the Russian by Nathan Haskell Dole. Retrieved August 1, 2015 from: littp:/ / www.arcliive.org/detaijs/annakareninatolsootolsiala

[13] Ushakov dictionary, dic.academic.ru.ru, https://slovari.yandex.ru.

[14] Volkov, V. (2013). Osnovy filologii. Antropocentrizm, jazykovaja lichnost' i pragmastilistika teksta: Kurs lekcij [Philology Essentials. Anthropocentrism, Linguistic Identiti and Pragmastylistics of Text: Coursebook]. Tver': Izdatel' Kondrat'ev A.N.

[15] Толстой, Л.Н. Анна Каренина [Anna Karenina]. Retrieved August 1, 2016 from: http:/ /loveread.ws $/$ read_book.php?id=3621\&p=37. 